\title{
Jezioro siarki i ognia w Księdze Apokalipsy św. Jana
}

\section{Lake of fire and brimstone in the Book of Apokalypse of saint John}

Słowa klucze: jezioro ognia i siarki - piekło w Apokalipsie - tło starotestamentowe teologia obrazu piekła w Ap.

Key words: keys: lake of fire and brimstone - inferno in Apocalypse - background of Old Testament - theology of inferno in Apocalypse.

\section{Wstęp}

W

przestrzeni szeroko pojętej dyskusji na tematy teologiczne pojawia się stale konieczność podejmowania nowych problemów, dokonywania nowych precyzacji w kwestiach, które stają się mniej zrozumiałe, nieadekwatne do zmieniającej się rzeczywistości współczesnej ludzkości. Istnieje jednak szereg tematów teologicznych, które schodzą dziś jakby w cień. Są raczej pomijane w dyskusji naukowej, wydają się „staroświeckie” lub zbyt odległe od oczekiwań współczesnego człowieka, a nawet dzisiejszych chrześcijan. Do takich kwestii można chyba zaliczyć prawdy związane z teologiczną wizją rzeczy ostatecznych. W Kościele katolickim należą do nich śmierć, sąd ostateczny, piekło, czyściec i niebo. Szczególnie temat piekła, wydaje się sporym anachronizmem, dlatego jest praktycznie nieobecny we współczesnym kaznodziejstwie ${ }^{1}$.

W poniższym artykule podjęto próbę przybliżenia Czytelnikowi jednego z symboli ściśle związanego z biblijnym obrazem piekła. Jest to symbol jeziora ognia i siarki zawarty w szeregu tekstów Apokalipsy św. Jana. Symbol ten mocno

1 Być może staje się niekiedy przedmiotem tzw. „pogodnego” przepowiadania. Dowcip o piekle, o diabłach i kotłach ze smołą może być mile widziany jako przerywnik w przekazie treści odpowiednich do dzisiejszych czasów. 
wpłynął na popularne w świecie chrześcijańskim wyobrażenie piekła ${ }^{2}$. Wydaje się jednak, że często bywa traktowany zbyt powierzchownie. Dlatego podjęto próbę jego interpretacji z perspektywy teologiczno-biblijnej uwzględniającej wyjątkową oryginalność literacką i teologiczną Ap. Dokonano tego, omawiając krótko najpierw różne warianty symbolu „jeziora siarki i ognia” w kontekście Ap. Następnie wskazano na jego związki z literaturą starotestamentową, z literaturą międzytestamentową oraz na relację symbolu do pozostałych tekstów nowotestamentowych. W punkcie trzecim zaprezentowano możliwą gamę treści teologicznych, na które wskazuje także kontekst samej Ap.

\section{Różne sposoby prezentacji „jeziora siarki i ognia" w kontekście Ap}

Motyw ,jeziora siarki i ognia” pojawia się bezpośrednio w końcowych tekstach księgi: Ap 19,20;20,10.14-15;21,8. Teksty te występują w trzech mniejszych jednostkach strukturalnych należących do większej części Ap 19,11-22,5 kończącej wizje zawarte w Ap 4,1-22,5. Trzy mini jednostki, w których pojawia się „jezioro siarki i ognia” to Ap 19,11-21; 20,7-15 oraz 21,1-83. Ich wspólną płaszczyznę tematyczną stanowi proklamacja ostatecznego zwycięstwo Jezusa Chrystusa nad złem.

W Ap 19,11-21 zawarta jest wizja walki i zwycięstwa Chrystusa nad bestią, fałszywym prorokiem i królami ziemi oraz ich wojskami. Efektem walki jest schwytanie i wrzucenie bestii i fałszywego proroka do ,jeziora ognia płonącego

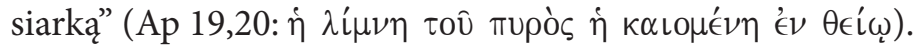

W kontekście Ap 20,1-15 odniesienia do „jeziora siarki i ognia” pojawiają się aż cztery razy. Nie występuje jedynie w wizji tysiącletniego królestwa w Ap 20,1-6. W Ap 20,7-10 zawarty jest obraz ostatniej walki szatana przeciw Bogu. W jej efekcie zostaje on wrzucony do ,jeziora ognia i siarki” (Ap 20,10:

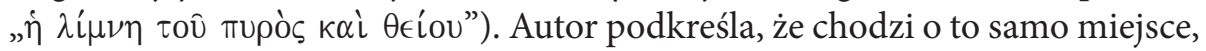
w którym znajdują się już bestia i fałszywy prorok, a przebywanie w nim jest związane z wiecznym cierpieniem ${ }^{4}$. Ostatni etap Ap 20,1-15 stanowi opis sądu ostatecznego zawarty w ww. 11-15. Śmierć i Otchłań po wydaniu zmarłych, by zostali poddani osądowi zostają wrzucone do ,jeziora ognia” (Ap 20,14:

2 Zob. H. Vorgrimler, Storia dell'inferno. Il sorgere e il fiorire dell'idea dell'aldilà dall'antica Babilonia ai nostri giorni, Casale Monteferrato 1995, s. 83.

3 P. Prigent, L'Apocalypse de Saint Jean, Paris ${ }^{2} 2000$, s. 77.

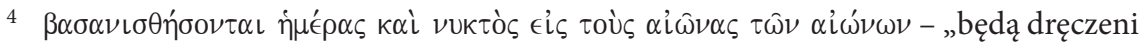
dniem i nocą na wieki wieków”. 


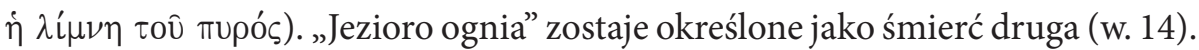
Los potępionych, którzy nie zostali zapisani w księdze życia to również wrzuce-

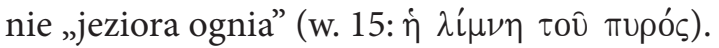

Po raz ostatni autor Ap odnosi się bezpośrednio do ,jeziora, które płonie

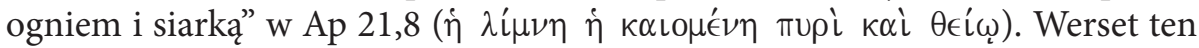
zamyka pierwszy etap wizji nowego stworzenia (Ap 21,1-8). Udział w nowej Jerozolimie jest możliwy tylko dla wiernych Bogu. Nie jest możliwy dla różnych kategorii złoczyńców wymienionych w Ap 21,8, których przeznaczeniem jest jezioro, w którym znajdują się szatan i potępieni (por. 20,14-15).

Wyraźną aluzję do rzeczywistości zawartych w obrazie jeziora ognia i siarki odnajdujemy w Ap 14,10. Tekst jest określany jako zapowiedź sądu ${ }^{5}$ i jest skierowany przeciw wyznawcom bestii. Jego szerszy kontekst stanowią wizje zawarte w Ap 12-14. Ap 14,10 stanowi integralną część Ap 14,6-136. Tekst Ap 14,6-13 poprzedza wizja Baranka i zbawionych w Ap 14,1-57. Bezpośrednio po nim następuje wizja aniołów- żeńców ziemi w Ap 14,14-20. W kontekście najbliższym Ap 14,10 stanowi część proklamacji trzeciego anioła (14,9-11). Schemat wizji w Ap 14,6-13 związany jest zasadniczo z prezencją trzech aniołów. Pierwszy z nich wzywa do wiernej służby Bogu (w. 6-7). Drugi zwiastuje upadek Babilonu (w. 8). Anioł trzeci koncentruje się na ostrzeżeniu potencjalnych czcicieli bestii (w. 9-11). Ap 14,12 stanowi pauzę i zachętę do pogłębionej refleksji nad sytuacją chrześcijan (por. 13,10) ${ }^{8}$. Natomiast Ap 14,13 zawiera relację o usłyszanym przez autora Ap błogosławieństwie.

Ap 14,9-11 otwiera i zamyka motyw czcicieli bestii i jej obrazu oraz jej pieczęci (w. 9b.11b). Powtórzenie to obejmuje treść przestrogi, która wyrażona została dwustopniowo. Etap pierwszy to odniesienie do symbolu kielicha gniewu Boga (por. Ap 18,3; Iz 51,17.22; Jr 25,11; 49,12; 51,11, itd.) ${ }^{9}$. Etap dugi to zapowiedź dręczenia wyznawców bestii ogniem i siarką wobec aniołów i Baranka

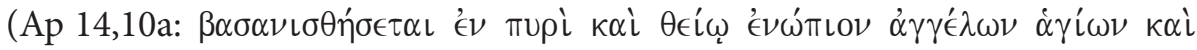

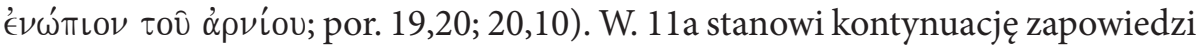

5 P. Prigent, L'Apocalypse de Saint Jean, Paris ${ }^{2} 2000$, s. 337.

6 J. Lambrecht, „A Structuration of Rev 4,1-22,5”, w: L'Apocalypse johannique et l'Apocalyptique dans le Nouveau Testament, red. J. Lambrecht, Leuven 1980, s. 97-98; D.E. Aune, Revelation 6-16, Nahsville 1998, s. 793

7 Zob. Z. Żywica, Tożsamość stu czterdziestu czterech tysięcy wykupionych z ziemi, „Forum Teologiczne” 1 (2000), s. 145-170.

8 Por. D. Kotecki, Duch Święty w zgromadzeniu liturgicznym w świetle Apokalipsy św. Jana, Warszawa 2006, s. 392-394.

9 D.E. Aune, Revelation 6-16, s. 797. 
kary z w. 10b, podkreślając, że „dym ich udręki wznosi się na wieki wieków i nie mają odpoczynku dniem i nocą"10.

Symboliczne elementy pokrewne wobec obrazu jeziora ognia i siatki (Ap 19,20; 20,14-15; 21,8) oraz wobec ognia, siarki i dymu (Ap 14,10-11) pojawiają się także w innych tekstach Ap. Należy do nich przede wszystkim wizja konnicy z Ap 9,17-18. Z pysków koni wydobywa się śmiercionośne dla części

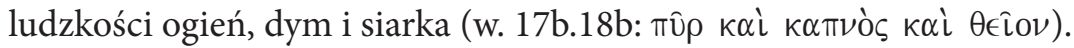

Teksty bezpośrednio traktujące o jeziorze ognia i siarki pozostają w ścisłym związku z teologicznym crescendo Księgi. Posiadają bowiem silne zabarwienie eschatologiczne. Proklamacja z Ap 14,10-11 oprócz niewątpliwej perspektywy eschatologicznej, posiada charakter bezpośredniej zachęty i przestrogi, by wytrwać na drodze wiary chrześcijańskiej.

\section{Pochodzenie symbolu}

W relacji do tekstów starotestamentowych apokaliptyczny symbol jeziora gorejącego ogniem i siarką budzi szereg skojarzeń, choć dotyczą one przede wszystkim ognia i siarki. Samo pojęcie $\dot{\eta} \lambda \grave{i} \mu \nu \eta$ - „jezioro, staw"11 jest bardzo rzadkie w literaturze biblijnej i najczęściej występuje właśnie w omawianym kontekście apokaliptycznego symbolu kaźni (por. Łk 5,1-2; 8,22-23.33).

Wydaje się, że w przypadku symboli ognia i siarki podstawowe znaczenie posiada finał opowiadania o ukaraniu Sodomy i Gomory ${ }^{12}$. Sodoma i Gomora, miasta w okolicy Jordanu, otoczone żyznymi terenami (por. Rdz 13,10-13) z powodu swoich grzechów zostały ukarane przez Boga (Rdz 19,1-29). Deszcz siarki i ognia spadł z nieba niszcząc miasta, mieszkańców oraz okoliczną ro-

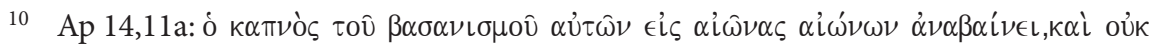

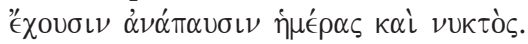

11 W. Bauer, Wörterbuch zum Neuen Testament zu den Schriften des Neuen Testaments und der frühchristlichen Literatur. 6. völlig neu bearbeuteite Auflage von Kurt un Barbara Aland, Berlin - New York 1988, kol. 964 w odniesieniu do Ap jako przede wszystkim jako „bajoro” („Pfuhl”). Pozostałe znaczenia to „jezioro, staw”. Podobnie H.W. Batsch, $\lambda i ́ \mu \nu \eta$, w: Exegetisches Wörterbuch zum Neuen Testament, opr. H. Balz, G. Schneider, t. II, Stuttgart - Berlin - Köln ${ }^{2}$ 1992, kol. 873 - w relacji do Ap preferuje znaczenie bajora („Pfuhl”). Pozostałe znaczenia to „jezioro”, „staw”. R. Popowski, Wielki Słownik greco-polski Nowego Testamentu, Warszawa 1994, s. 368 podaje jedynie znaczenie „jezioro”.

12 Zob. M. Karczewski, Reinterpretacja Księgi Rodzaju w Apokalipsie św. Jana, Olsztyn 2010, s. 163-175. 
ślinność (Rdz 19,24) ${ }^{13}$. W innym miejscach księgi autor Ap nawiązuje także do związanego z historią Sodomy i Gomory motywu dymu, który unosił się nad nimi po dokonanej karze (por. Ap 9,2.17-18) ${ }^{14}$. Zapowiedź kary dla Goga i Magoga w Ez 38,22 zawiera szereg elementów. Wśród nich, obok zarazy i krwi, ulewnego deszczu, wielkiego gradu pojawiają się ogień i siarka ${ }^{15}$. W Ap 20,10 przedstawiono efekt apokaliptycznej walki Goga i Magoga, którą jest wrzucenie diabła do jeziora ognia i siarki. Zbieżność jest ewidentna ${ }^{16}$. Niekiedy sugeruje się związek z Dn 7,11, gdzie ciało bestii zostaje wrzucone do ognia ${ }^{17}$. Motyw palącego wiatru oraz deszczu ognia i siarki jako kary dla bezbożnych pojawia się także w Ps 11,6. Niekiedy sugeruje się, że symbole ognia i dymu nawiązuje

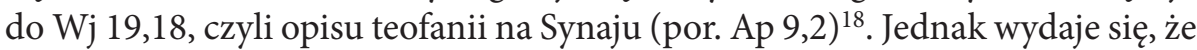
w przypadku obrazu jeziora ognia i siarki większe znaczenie posiada nawiązanie do kary, która spotkała grzeszne miasta.

Temat kary przeznaczonej dla bezbożnych pojawia się często w literaturze międzytestamentowej. W 1 Hen 90,24-26 aniołowie wrzucają potępionych do "otchłani pełnej płonącego ognia" ${ }^{19}$ (por. 1 Hen 48,9; 54,1; 62,12; 108,14-15). W 4 Ezd 7,36.39 wizjoner ukazuje symboliczny piec Gehenny (por. 2 Krl 16,3; 23,10; Jr 7,31-32). Jest to miejsce „ognia” i „męczarni” ${ }^{20}$ (por. Ap 14,10; 2 Hen 10). Motyw kary ognia, która dosięgnie upadłe duchy pojawia się także w qumrańskiej Regule Wojny. Zostaną one spalone jak słoma (1QM 11) ${ }^{21}$.

Niekiedy sugeruje się, że rzadkie odniesienie do ognistego jeziora świadczy o jakimś typie zależności do obrazu ,jeziora ognia” zawartego w egipskiej Księdze Umarłych 17,40-42;24,4; 175,15.20. Dodatkowe wpływy literatury grecko-rzymskiej miały być jedną z przyczyn pojawienia się tego symbolu w Ap ${ }^{22}$. Jednak w środowisku egzegetów jest to opinia dość odosobniona.

13 Zob. D.M. Howard, Sodom and Gomorrah revisited, JEST 27/4 (1984), s. 385$-400$

M. Karczewski, Reinterpretacja Ksiegi Rodzaju, s. 165-170.

15 Zob. R.H. Mounce, The Book of Revelation. Revised, Grand Rapids - Cambridge 1997, s. 358-359.

16 Zob. D.E. Aune, Revelation 17-22, s. 1094-1095.

17 G.K. Beale, The Book of Revelation, Grand Rapids - Cambridge 1999, s. 969-970.

18 Zob. D.E. Aune, Revelation 17-22, s. 1066.

19 Przekład R. Rubinkiewicz, I Księga Henocha (Księga Henocha etiopska), w: Apokryfy Starego Testamentu, opr. R. Rubinkiewicz, Warszawa 1999, s. 179

20 Przekład S. Mędala, IV Księga Ezdrasza, w: Apokryfy Starego Testamentu, s. 385.

21 Przekład F. Garcia Martinez, Testi di Qumran, Brescia 1996, s. 209.

22 D.E. Aune, Revelation 17-22, s. 1066-1067. 
Na tle pozostałych pism nowotestamentowych apokaliptyczny obraz jeziora ognia i siarki zachowuje swoją oryginalność, ale jednocześnie potwierdza zawartą w nich koncepcję istnienia pośmiertnego miejsca odrzuconych przez $\mathrm{Boga}^{23}$. Jest to symboliczne, związane $\mathrm{z}$ ogniem, miejsce nieustannego cierpienia (por. Mk 9,43.45.47; Mt 10,28). Z tego miejsca nie ma drogi powrotnej (Łk 16,24-26). Miejsce potępionych związane jest także mocno z perspektywą eschatologiczną Nowego Testamentu (Mt 25,41; Łk 17,29-30; por. 1 Kor $15,26)$. Na tle innych tekstów nowotestamentowych oryginalność obrazu apokaliptycznego wyraża się przede wszystkim w fakcie użycia symbolu jeziora, częstego używania odniesienia do siarki oraz braku jakiejkolwiek wzmianki o Gehennie.

Aluzję do jeziora ognia i siarki znajdujemy w greckim fragmencie (23) Apokalipsy Piotra (ok. 135 po Chr). W tekście Apokalipsy Piotra znajduje się obraz wielkiego rowu, będącego rodzajem głębokiego dołu, pełenego różnych rodzajów potępionych, którzy nieustannie płoną w wiecznym, nieugaszonym ogniu $^{24}$. W opinii egzegetów, Apokalipsa Piotra mogła znajdować się pod wpływem $\mathrm{Ap}^{25}$. Także przywoływane niekiedy inne apokryfy nowotestamentowe są późniejsze od Ap i mogły czerpać z jej obrazów ${ }^{26}$. Podobnie ma się rzecz z pismami pierwszych pisarzy chrześcijańskich ${ }^{27}$.

Wydaje się, że szukając analogii lub ewentualnych źródeł, które mogły zainspirować autora Ap do posłużenia się symbolem jeziora ognia i siarki, należy wziąć pod uwagę jeszcze jedną, być może fundamentalną, cechę symboliki Ap. Jest nią zdolność do tworzenia nowych symboli przywołujących te już istniejące w literaturze biblijnej oraz szeroko pojętym środowisku kulturowo-religijnym odbiorców księgi ${ }^{28}$. Wydaje się, że do takich symboli należy także jezioro ognia i siarki.

23 Por. G.R. Osborne, Revelation, Grand Rapids 2002, s. 690.

24 H. Vorgrimler, Storia dell'inferno, s. 83-86, uważa tekst z Apokalipsy Piotra za decydujący w procesie powstania chrześcijańskiego wyobrażenia piekła.

25 P. Prigent, L’Apocalypse de Saint Jean, s. 424.

26 Zob. Wniebowzięcie Izajasza 14,4; Wyrocznie Sybillińskie 2,292-310; 4,184-186.

27 H. Vorgrimler, Storia dell'inferno, s. 94-112.

28 M. Karczewski, Reinterpretacja Księgi Rodzaju, s. 50-54. 


\section{Wymiar teologiczny ,jeziora siarki i ognia"}

\subsection{Kara}

Ważny wymiar teologii symbolu jeziora siarki i ognia związany jest z wyrazistym utożsamieniem go z karą, którą wymierza sam Bóg. Stanowi jeden z głównych elementów eschatologii Ap. Tak jak pewna jest możliwość życia wiecznego, powrotu do nowego raju, tak oczywista jest groźba poniesienia wiecznej klęski, którą symbolizuje jezioro ognia i siarki. Autor Ap stara się uświadomić wspólnocie wierzących, że jezioro ognia i siarki stanowi realne zagrożenie dla tych, którzy trwają po stronie Babilonu (por. Ap 14,10). Babilon i ci, którzy konstruują i odrzucają autorytet Boga są skazani na porażkę (por Ap 17-18). Bezpardonowa walka z Bogiem prowadzona przez szatana i jego współpracowników, choć jeszcze trwa, dzięki męce i zmartwychwstaniu Baranka już jest wygrana (Ap 12,7-9 ${ }^{29}$. Ostateczny finał nastąpi i jego efekt będzie oczywisty $\left(\right.$ Ap 17,14) ${ }^{30}$. Zbawienie, udział w życiu Baranka to jednocześnie uniknięcie złego wyboru, beznadziejnego błędu, jaki popełniają przeciwnicy Baranka. Baranek uwalnia wierzących od konsekwencji upartego, demonicznego trwania w grzechu (por. Ap 12,10-12). Obmycie szat we krwi Baranka uwalnia od niebezpieczeństwa potępienia (Ap 7,14; 22,14). Baranek daje udział w nieskończonym życiu Boga (Ap 7,17).

W perspektywie teologicznej Ap nie ma miejsca na przeakcentowanie groźby potępienia lub typowe dla niektórych apokaliptycznych pism apokryficznych detaliczne rozpatrywanie wymyślnych, odpowiednich do popełnionych win, rodzajów kar piekielnych ${ }^{31}$. Jednakże w Ap nie ma także trzeciej drogi, neutralnej wobec Boga. Radykalizm Ap jest uderzający. W perspektywie eschatologicznej można być tylko za albo przeciw Bogu. Każdy poniesie nieuchronnie konsekwencje swoich wyborów. Oczywiście wyraźny dualizm Ap zawarty w bardzo pojemnym teologicznie języku symboli nie wyklucza przeświadczenia chrześcijan, że po stronie Boga można opowiedzieć się, nawet Go

29 Pozorne zwycięstwa szatana przemienią się w ostateczny tryumf Baranka i Kościoła, zob. K. Kościelniak, Zło osobowe w Biblii. Egzegetyczne, historyczne, religioznawcze i kulturowe aspekty demonologii biblijnej, Kraków 2002, s. 147.

30 M. Karczewski, Jezus Chrystus jako Król królów i Pan panów (Ap 17,14b; 19,16) na tle teologii Apokalipsy, w: Scripturae Lumen 1. Ewangelia o Królestwie, red. A. Paciorek, A. Czaja, A. Tronina, Lublin 2009, s. 279-280.

31 H. Vorgrimler, Storia dell'inferno, s. 83. 
nie znając (Rz 2,14; 10,14-15). Jednak ostateczny sąd Boga dopuszcza istniejące dwie możliwości: nową Jerozolimę lub jezioro ognia i siarki (Ap 20,15).

\subsection{Wykluczenie}

Nagroda, czyli wejście do nowego Edenu, niebiańskiej Jerozolimy jest równoznaczne z udziałem w wiecznym życiu Boga. Bóg jest Ojcem (Ap 21,7), jest źródłem nieskończonego życia (Ap 22,1), jest świątynią (Ap 21,22). Wszyscy zbawieni jednoczą się w Bogu. Pierwszy wymiar kary to przede wszystkim niemożność udziału w odnowionym świecie. Są tacy, którzy pozostają na zewnątrz miasta (Ap 22,15; por 22,3). Można zastanawiać się, czy wykazy grzechów dyskwalifikujących do wejścia do nowej Jerozolimy powinny być traktowane literalnie jako spis konkretnych nadużyć, czy odnoszą się do różnych form pogań-

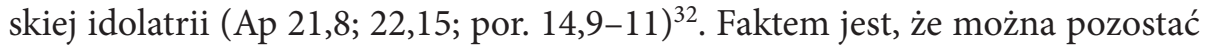
na zewnątrz, co jest jednoznaczne z udziałem w rzeczywistości ukrytej w symbolu jeziora ognia i siarki. Sam symbol, poprzez swój bliski związek z opowiadaniem o grzesznych Sodomie i Gomorze wskazuje na pewną stałą cechę działania Boga. Bóg nie zbawia na siłę. Za odrzucenie możliwości nawrócenia i trwanie w grzechu trzeba będzie ponieść konsekwencje. Wspaniałość nagrody pozostaje w niezwykłym kontraście do oczywistej porażki zwolenników zła.

Warto zauważyć, że w perspektywie teologicznej Ap nie wszyscy są wykluczani, czyli wrzucani do jeziora ognia i siarki w sposób jednakowy (Ap 19,20$-21)^{33}$. Rzeczywistości czysto demoniczne, z natury wrogie Bogu, są wykluczane w konsekwencji symbolicznej walki i wrzucane żywcem do piekła (Ap $19,20 ; 20,10)$. Sytuacja ta podkreśla czysto antyboski, buntowniczy charakter szatana. Ludzie, nawet wtedy, gdy nierozważnie stanęli po stronie zła, są traktowani inaczej i przysługuje im sąd (Ap 19,21; 20,7-10.12-13). W tym ledwo zauważalnym detalu może być ukryta informacja o tym, że Bóg do końca próbuje uratować człowieka przed potępieniem.

\subsection{Pasywność}

Symbole ognia i siarki przywołują sytuację Sodomy i Gomory po wykonaniu kary Bożej. Urodzajne tereny zamieniły się w pustkowie. Symbolem braku wegetacji jest siarka. Środowisko zostało zatrute, pozbawione oznak życia. Śmierć

32 Katalog występów obejmuje przewinienia moralne i religijne, zob. M. Karczewski, Reinterpretacja Księgi Rodzaju, s. 113.

33 Zob. H.U. von Balthasar, Księga Baranka. Medytacje nad Apokalipsą św. Jana, Kraków 2005, s. 91. 
druga, która dotyka potępionych, to nie ich unicestwienie, ale odmiana w sposobie ich egzystencji (por. Ap 2,$11 ; 20,14)^{34}$. Jezioro siarki i ognia to metafora rzeczywistości, którą możemy porównać do miejsca nieużytecznego, bez żadnych perspektyw na przyszłość, bez żadnej nadziei na jakąkolwiek poprawę losu (por. Mdr 1,16). Ogień i siarka pozostają w silnym kontraście do obfitych wód życia i zwielokrotnionego Edenu, który symbolizuje maksimum żywotności, totalny brak wszelkiego braku i negatywnej sterylności. Jezioro ognia i siarki, to używając współczesnych porównań, miejsce maksymalnie skażone, nieurodzajne ${ }^{35}$. Jest konsekwencją bezpowrotnego oddzielenia do Źródła wszelkiego życia. Symboliczne wrzucenie do jeziora ognia i siarki, krainy umarłych i śmierci kończy sąd i bezpośrednio poprzedza wizję nowego nieba i nowej ziemi (Ap 20,14;21,1). Także ono w pewien sposób wpisuje się w klimat dezaktywacji, unieruchomienia, wyrzucenia na spalenie. Bóg ostatecznie usuwa na bok rzeczywistości starego, grzesznego świata, ponieważ nie ma żadnej możliwości, by stały się częścią nowego stworzenia (Ap 21,4d). Także „twórczość" śmierci ostatecznie ustanie ${ }^{36}$.

\subsection{Udręka}

Ogień i siarka pozostają w relacji do mąk, jakim poddani są wrzuceni do piekła. W Nowym Testamencie termin „ß $\beta \sigma \alpha \nu i \zeta \omega ”$ wyraża katusze zarówno w wymiarze cielesnym, jak i psychicznym ${ }^{37}$. Sprawiedliwi doznają udręki, widząc zło (por. 2 P 2,8). Dręczenie bólem może także dotyczyć sfery fizycznej (Ap 9,5; 11,$10 ; 12,2$; por. Mt 18,34). W każdym przypadku chodzi o trudną do zniesienia formę cierpienia, której intensywność określa się jako tortura, męczarnia,

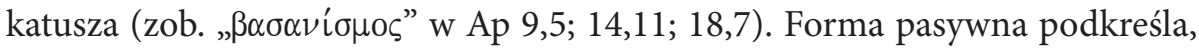
że wrzuceni do jeziora ognia i siarki nie mają żadnej możliwości, aby uniknąć cierpienia. W opinii egzegetów autor Ap podkreśla namacalny, okrutny charakter tortur. Dokonuje tego wyraźnie używając w opisie położenia potępionych w Ap 14,10 sformułowania „będą dręczeni ogniem i siarką”. Jest to zatem ból spalania ciała, jeden z najbardziej dotkliwych dla człowieka. Podobnie w przy-

34 G. Ravasi, Apokalipsa, Kielce 2002, s. 177.

35 P. Prigent, L’Apocalypse de Saint Jean, s. 10 mówi o wieczności bez zmartwychwstania.

36 R. Bauckham, Judgement in the Book of Revelation, „Ex Auditu” 20 (2001), s. 17-21 mówi o swoistej śmierci śmierci.

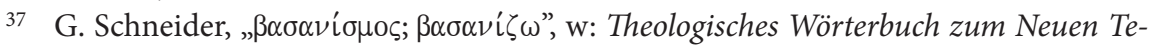
stament, red. G. Kittel, G. Friedrich, t. 1, Stuttgart 1933, s. 561; R. Popowski, Wielki Słownik greco-polski, s. 92-93. 
padku wrzucenia do piekła żywcem szatana i jego kolaborantów (Ap 19,20; $20,10)$ oprócz ewidentnego nawiązania do losu buntowników wobec Boga w Lb 16,33 można dopatrywać się podkreślenia wyjątkowego stopnia dotkliwości ponoszonej kaźni. Wymiar psychiczny udręki związany jest z poruszonymi powyżej wiecznym wykluczeniem i brakiem udziału w wiecznym życiu Boga, czyli ze świadomością nieodwracalnej i całkowitej porażki. W Ap 14,10 stwierdza się, że udręki potępienia będą dokonywały się wobec Baranka i aniołów. Ten fakt podkreśla zawodność planów nieprzyjaciół Baranka. Prawdziwym Panem historii jest Baranek. Ci, którzy uparcie trwali po stronie fałszywych kultów, są skazani na konsekwencje swoich czynów. Jedną z tych konsekwencji jest zesłane przez Boga cierpienie ${ }^{38}$.

Autor Ap unika precyzyjnego określenia, na czym miałoby polegać cielesne bądź psychiczne cierpienie odrzuconych. Sytuacja nie zmienia się nawet, gdy potraktujemy opisy cierpienia jako metafory udręki duchowej ${ }^{39}$. Są to katusze, które ogarniają całą potępioną osobę. Należy także podkreślić, że są one wieczne i nieodwołalne. Autor Ap podkreśla, że beznadziejność położenia potępionych związana jest także z sytuacją bezustannej, nieprzerwanej udręki, która trwa „dniem i nocą i na wieki wieków” (Ap 14,11; 20,10) ${ }^{40}$. Jezioro płonie w ogniu i siarce i nie gaśnie ${ }^{41}$. Wobec nich, chwilowa ziemska męka chrześcijan prześladowanych za wierność Chrystusowi, choć trudna i wymagająca samozaparcia, staje się tylko jednym $z$ etapów drogi do życia bez cierpienia i łez (Ap 2,8-11;21,3-4).

\section{Zakończenie}

Jezioro ognia i siarki jest symbolem, który zaskakuje głębią teologicznej treści. Nawiązując do radykalnej odmiany losu Sodomy i Gomory oraz do innych tekstów biblijnych i pozabiblijnych, zachowuje daleko idącą oryginalność. W jeziorze tym, znaku zasłużonej kary, znajdują się przeciwnicy Boga i Baranka,

38 W Ap 14,10 zapowiedź dręczenia ogniem i siarką poprzedzona jest przywołaniem symbolu kielicha gniewu Bożego. Nawiązując do zastosowanego symbolicznego języka Ap, można stwierdzić, że Bóg nie ma wątpliwości co do zasadności kary, jest ona efektem obrazy Jego majestatu i naiwnej wiary, że można sobie z Niego naigrawać (por. Ap 14,8.10; 16,19; 18,3; 19,15), zob. R. Miggelbrink, Gniew Boży. Znaczenie pewnej gorszacej tradycji biblijnej, Kraków 2005, s. 93-95.

39 O udręce duchowej mówi R. Popowski, Wielki Słownik greco-polski, s. 93.

40 Trudno zgodzić się z twierdzeniem R. Miggelbrunka, że w Ap 20,15 potępieni zostają zlikwidowani, zob. tenże, Gniew Boży, s. 94.

41 M. Karczewski, Reinterpretacja Księgi Rodzaju, s. 175. 
którzy nie weszli do nowej Jerozolimy. Wobec pełni życia, która jest udziałem zbawionych, jezioro jawi się jako miejsce pozbawione nadziei, bez żadnej możliwości odmiany losu. Jezioro siarki i ognia jest także symbolem cierpienia, a właściwie udręki obejmującej całego potępionego. Ma ona także wymiar psychiczny, jest efektem świadomości poniesionej klęski, dokonanych złych wyborów, bezmyślnie odrzuconej szansy.

Obraz jeziora potępionych poraża beznadzieją. Dla odbiorców Ap stanowi przestrogę, uświadamia, że walka szatana z Bogiem dzieje się naprawdę. Obmycie szat i wierność Barankowi prowadzą nie tyle do dobrego samopoczucia i komfortu moralnego. Są szansą na udział w nieograniczonym, wiecznym życiu.

\section{Summary}

Among the various theological themes present in the Book of Revelation is also the less popular. They are too far from reality. Old- fashioned, outdated. One of them is a symbol of hell - the lake of fire and brimstone. In this paper we attempt to theological-biblical analyze of this symbol. It contains three main points: different ways of presenting the symbol in the Ap; possible relationship with the Old Testament and the main theological associated with the image of hell. Among them should be mentioned: the penalty; exclusion; lack of prospect for the future; the anguish of damned. Hell seems to be so as the end of the enemies of God. 